sawdust, are prepared and the cutting inserted in the compost, one per basket. The cuttings are then rooted in a shaded glasshouse with controlled humidity at 100 per cent. It is stated that one unit could supply 30,000 plants ready for field planting.

Techniques for the complete study of the contents of a single pod have been taken a stage further by the use of an improved microfermentary. Improvements have also been effected in the solar fermentary, which is of a capacity intermediate between the normal fermentation box (or sweatbox) and the microfermentary.

Other papers in this report are concerned with such topics as physical measurements of soil, the effect of shade and of mulching on soil temperature, nitrogen partition in the normal cacao leaf (as a contribution to an understanding of the rate of development of some pest populations), the susceptibility of various selections to witches' broom disease, spraying against this disease, and various entomological and cultural studies. Researches in progress and those contemplated are also briefly annotated.

\section{MICRO-FOSSILS IN EARLY FLORAS}

A

TTENTION has been directed to the important bearing of certain micro-fossils on our knowledge of the nature and composition of Pre-Carboniferous floras in Canada by N. W. Radforth and D. C. McGregor (Canadian J. Bot., 32, 5, 601 ; 1954).

It has now been ascertained that, in Canada, rocks of Devonian age are associated with the occurrence of oil and gas. In some of these oil-yielding areas, which present serious difficulties to the stratigrapher because of the presence of 'unfossiliferous' sediments, that is, barrenness of plant remains as macro-fossils, it appears that the investigation of the micro-fossils is likely to afford a tool of practical value, and to yield information of very great interest to the palæobotanist; for the Devonian period has long been held to be one of critical importance in the evolution and development of the flora of the land.

Fifty-six recently discovered spores and spore-like micro-fossils from Canadian non-coaly deposits of Middle and Upper Devonian age have now been described and classified by these investigators. The manner of occurrence of these fossils suggests that they may probably be useful in ascertaining biostratigraphical entitios and in the further investiga. tion of oil-bearing rocks.

In relation to the evolution of plants, these microfossils afford evidence of a more complex and more highly evolved Devonian flora than has been apparent from the macro-fossil record. Furthermore, preliminary investigations have disclosed spores of comparable abundance and of only slightly less complexity in rocks of Lower Devonian and Silurian a.ge.

On the preliminary evidence now presented, that is, of the existence of large and diversified spore populations in different strata, even in those of Lower Devonian and Silurian age, it appears that the land flora of the Devonian period was both varied and extensive, this being contrary to the commonly held view. The discovery of relatively complex microfossils in Silurian rocks containing Monograptus is important from the botanical point of viow : it indicates that the complexity of form and structure which are normally associated with the vascular plants probably came into existence very much earlier than has usually been assumed, that is, on the evidence derived from the study of such stems, leaves and sporangia as have come to light. Special interest is attached to a Devonian micro-fossil which in appearance resembles angiosperm pollen, though, as the authors are careful to point out, any conclusion about it at this stage would have to be viewed with the greatest caution.

\section{RESPIRATORY PIGMENTS OF RHODOSPIRILLUM RUBRUM}

\author{
By $D_{R}$. BRITTON CHANCE and \\ DR. LUCILE SMITH \\ Johnson Foundation, University of Pennsylvania
}

CENSITIVE spectroscopic methods for recording $\checkmark$ differences of optical density between aerobic and anaerobic suspensions of many types of bacteria have made possible accurate identification of the patterns of their cytochromes, flavoproteins and pyridine nucleotide enzyme systems ${ }^{1}$. We report here a study of the respiratory pigments of Rhodospirillum rubrum, the bacterium in which Duysens ${ }^{2}$ and Vernon and Kamen ${ }^{3}$ have concluded that a cytochrome with an absorption spectrum similar to that of cytochrome $c$ is oxidized in a photochemical reaction.

Spectroscopic changes occurring when the aerobic bacterial suspension became anaerobic were recorded at a series of different wave-lengths from 650 to $390 \mathrm{~m} \mu$ (as in Fig. $1 A$ ) by means of a double-beam apparatus ${ }^{4}$. In each case the difference between the given wave-length and some reference wave-length was recorded ; this eliminated any interference which might have resulted from changes in the lightscattering properties of the bacteria. In some experiments the difference in optical density between two forms of the pigments in two different cuvettes was recorded by means of a split-beam instrument ${ }^{5}$, as illustrated in Fig. $1, B$ and $C$. Photochemical effects upon the spectrum (Figs. 2 and 3 ) were recorded with the same apparatus that was developed for measuring the photodissociation difference spectra of the carbon monoxide compounds of cytochrome oxidases ${ }^{6}$. Here infra-red illumination was obtained from a tungsten lamp through two thicknesses of Wratten $88 \mathrm{~A}$ filter plus Corning 2424. Neutral filters of density between 0.5 and 2.0 were also added until the observed effect of illumination of aerobic cells was very small, similar to that illustrated in Fig. $3 \mathrm{~A}$. The bacteria were obtained through the kindness of Dr. M. D. Kamen and were grown as described by him $^{7}$, except that tap water and twice the concentration of yeast extract and biotin were used. For measurements in the Soret region of the spectrum, cells obtained after two to three days growth were used directly; these had an optical density at $800 \mathrm{~m} \mu$ of about $1.0 \mathrm{~cm} .^{-1}$. Denser suspensions for use in the visible region of the spectmum were obtained by centrifuging the cells, then suspending them in the supernatant fluid.

\section{Dark Reactions of the Pigments}

The difference spectra plotted in Fig. $1 A$ and Fig. $2 A$, curves a (difference in optical density 